\title{
Nilai Pendidikan Karakter Motif Batik Dewa Ruci Karya Sapuan Ditinjau dari Perspektif Thomas Lickona
}

\section{The Value of Character Education in Dewa Ruci's Batik Motif by Sapuan Viewed from Thomas Lickona's Perspective}

\author{
Dian Triwulandari
}

SMK Negeri 1 Kepanjen, Malang, Jawa Timur Indonesia

\begin{abstract}
Abstrak
Motif Batik Dewa Ruci adalah karya Sapuan seorang guru Sekolah Menengah Pertama (SMP) dari Pekalongan. Dewa Ruci adalah sebuah karya batik unik yang merepresentasikan cerita hidup perjalanan Bima, seorang tokoh pewayangan. Kisah perjalanan hidup seorang Bima yang tervisualisasikan melalui motif ini membawa nilai pendidikan karakter yang sarat akan nilai kebaikan. Penelitian ini mengkaji nilai pendidikan karakter yang terkandung dalam motif Batik Dewa Ruci ditinjau dari perspektif seorang tokoh pendidikan karakter Thomas Lickona. Metode yang digunakan dalam pengkajian ini adalah metode deskriptif kualitatif, menggunakan data wawancara dengan pencipta batik untuk melihat motivasi instrinsik karya, pengamatan terhadap batik, dan di dukung dengan data kepustakaan. Analisis data menggunakan pendekatan hermeneutika, yakni menafsirkan ekspresi yang tampak dalam visual batik. Hasil pengkajian menunjukkan bahwa Batik Dewa Ruci karya Sapuan memuat nilai karakter kebaikan Thomas Lickona, Diharapkan penelitian ini dapat menginspirasi bagi para pendidik dan perupa, untuk dapat menyelipkan nilai pendidikan dalam karya seni, dan bagi para pembaca untuk dapat memahami makna filosofis batik Dewa Ruci.
\end{abstract}

Kata Kunci: Batik; Pendidikan karakter; Thomas Lickona

\begin{abstract}
Dewa Ruci's Batik motif is the work of Sapuan a Junior High School (SMP) teacher from Pekalongan. Dewa Ruci is a unique batik work that represents the life story of the journey of Bima, a puppet character. The story of Bima's life journey visualized through this motif brings the value of character education which is full of goodness values. This research will examine the value of character education contained in the Batik Dewa Ruci motif in terms of the perspective of character education Thomas Lickona. The method used in this study is a qualitative descriptive method, using interview data with the creator of the batik to see the intrinsic motivation of the work, observations of the batik, and supported by library data. Data analysis uses a hermeneutic approach, which is interpreting the expressions that appear in the visuals of the batik. The results of the study show that the Batik Dewa Ruci by Sapuan contains the character values of Thomas Lickona's kindness, It is hoped that this research can inspire educators and artists, to be able to insert value of character education into works of art, and for readers to be able to understand the philosophical meaning of Dewa Ruci's batik. Keywords: Batik; Character Education; Thomas Lickona
\end{abstract}

How to Cite: Triwulandari, D. (2021). Nilai Pendidikan Karakter Motif Batik Dewa Ruci Karya Sapuan Ditinjau Dari Perspektif Thomas Lickona. Jurnal Pendidikan dan Penciptaan Seni, 1(2) 2021: 46-57 


\section{PENDAHULUAN}

Seperti kita ketahui bersama bahwa pendidikan di Indonesia selama ini masih menekankan pada pemahaman ilmu secara kognitif dengan penekanan pada materi dalam ilmu pengetahuan, mengesampingkan nilai-nilai pendidikan karakter yang sejatinya diperlukan untuk membentuk karakter seseorang. Sehingga harus disadari bahwa carut marutnya negeri yang semakin sering kita lihat di layar televisi ataupun media sosial salah satunya disebabkan oleh karena menurunnya nilai-nilai karakter yang terdapat pada diri manusia Indonesia. Krisis moral yang terjadi pada masyarakat Indonesia dimulai dari kalangan terpelajar hingga para elite politik menunjukkan bahwa pendidikan agama dan moral yang diajarkan pada saat di bangku sekolah maupun perguruan tinggi, tidak memberikan dampak pada perubahan perilaku manusia Indonesia (Dalmeri, 2014). Bahkan yang terlihat adalah begitu banyak manusia Indonesia yang tidak lagi malu atau bahkan tidak menyadari bahwa perilakunya tidak koheren dan tidak lagi relevan antara ucapan dan tindakannya.

Pendidikan karakter sangat di butuhkan bagi manusia Indonesia untuk membentuk manusia yang berkarakter positif. Dalam lingkungan pendidikan semua komponen dalam pendidikan harus dilibatkan, yaitu isi kurikulum, proses pembelajaran dan penilaian, penanganan atau pengelolaan mata pelajaran, pengelolaan sekolah, pemberdayaan sarana prasarana, dan etos kerja seluruh warga sekolah (Mahliana \& Mustikarini, 2013). Naskah Kebijakan Nasional Pembagunan Karakter Bangsa, menguraikan bahwa terdapat beberapa alasan mendasar yang melatari belakangi pentingnya aspek pembangunan karakter bangsa, baik secara filosofis, ideologis, normatif, historis dan juga sosiokultural (Ariandy, 2019). Secara filosofis, pembangunan karakter bangsa merupakan kebutuhan asasi dalam proses berbangsa karena hanya bangsa yang memiliki karakter dan jati diri yang kuat yang akan bertahan sebagai suatu bangsa. Sementara itu Supranoto dalam (Munawaroh, 2019) menyatakan bahwa pendidikan karakter adalah segala usaha yang dilakukan oleh pendidik untuk membentuk karakter peserta didik. Sehingga dengan adanya karakter baik pada diri manusia, maka keindahan dan kesempurnaan jasmani manusia menjadi lebih indah dan lebih pantas. Karakter baik yang ada pada diri tiap-tiap manusia Indonesia inilah nantinya yang akan membawa bangsa Indonesia menjadi bangsa yang berperadaban maju dan besar. Penanaman nilai-nilai karakter dalam kehidupan amat sangat diperlukan karena dengan penanaman nilai karakter dapat membangun perkembangan pendidikan karakter di Indonesia dan dapat menjadi sebuah solusi permasalahan krisis karakter yang ada di Indonesia (Arifiyanti et al., 2018).

Menurut Thomas Lickona seorang tokoh pendidikan karakter, berpendapat bahwa kecerdasan dan berperilaku baik bukanlah hal yang sama (Lickona, 2012). Lebih jauh lickona menjelaskan bahwa pada masa yang lalu para pemangku kebijakan sejak zaman Plato telah membuat suatu kebijakan mengenai pendidikan moral yang secara sengaja dibuat sebagai bagian utama dari pendidikan sekolah. Mereka mendidik karakter masyarakat setara dengan pendidikan intelegensi, mendidik kesopanan setara dengan pendidikan literasi, mendidik kebijakan setara dengan pendidikan ilmu pengetahuan. Mereka pun telah mencoba untuk membentuk masyarakat yang dapat menggunakan intelegensi mereka untuk memberikan manfaat baik bagi masyarakat maupun bagi dirinya sendiri sebagai bagian dari masyarakat yang membangun kehidupan yang lebih baik. Sedemikian pentingnya sebuah pendidikan karakter bagi kehidupan manusia secara pribadi maupun dalam kontribusi manusia sebagai Sumber Daya Manusia bagi sebuah negara.

Pendidikan karakter bukanlah hanya menjadi kewajiban bagi sebuah lembaga pendidikan, namun juga semua pihak, termasuk masyarakat umum. Pendidikan karakter 
dalam lingkungan pendidikan formal dapat diselipkan atau dimasukkan pada semua bentuk dan jenis mata pelajaran, sementara itu dalam lingkungan pendidikan non formal dapat diterapkan dalam kehidupan sehari-hari bermasyarakat. Masyarakat di luar lingkungan pendidikan formal akan melihat dan mendengar kisah-kisah inspiratif dari lingkungan sekitarnya, dan kemudian meniru dan menerapkan dalam kehidupannya. Oleh karena itu menjadi kewajiban bersama untuk terus mempertontonkan kisah-kisah inspiratif yang baik bukan hanya carut marutnya negeri yang dipertontonkan dalam kehidupan melalui media massa.

Indonesia sesungguhnya adalah negara berbudaya luhur yang menyimpan ribuan kisah inspiratif dari pada pendahulu kita. Sayangnya kisah-kisah inspiratif ini semakin kurang di dengunggakan berganti dengan kisah masa kini yang lebih menggungah selera, cerita-cerita budaya asing yang lebih membanggakan untuk ditiru tetapi belum tentu bermanfaat bagi mereka. Sungguh sangat disayangkan, apabila krisis ini terus berlanjut tentulah pada saatnya kita akan benar-benar akan kehilangan jati diri kita sebagai bangsa timur yang berbudaya luhur dan menjunjung tinggi budayanya. Kenyataannya semakin sedikit orang-orang bergerak untuk terus menggaungkan kebaikan budaya Indonesia dalam rangka melanjtkan dan mewariskan karakter Indonesia yang baik dan luhur. Padahal karakter baik dapat diteruskan melalui keteladanan (Munawaroh, 2019).

Salah satu pelaku budaya yang masih terus berkomitmen untuk berkarya dan terus meneladankan karakter baik adalah Sapuan dengan karya-karya batiknya. Karya batik yang dalam motif nya sarat akan keteladanan karakter baik dalam kehidupan layak untuk diajarkan dalam pendidikan. Penanaman nilai-nilai karakter dapat diberikan melalui sebuah pembelajaran membatik dan mengapresiasi karya batik. Perihal ini dapat menjadi salah satu bentuk alternatif untuk mendidik sejak dini agar memiliki mental yang kuat akan masuknya pengaruh globalisasi, selain dapat membangun karakter manusia baik juga dapat menjadi kegiatan pengenalan sejak dini budaya dan kearifan lokal. Batik diakui tidak hanya oleh Indonesia tetapi juga oleh dunia bahwa batik menjadi salah satu wujud karya peradaban bangsa Indonesia yang luhur yang sudah sepatutnya dilestarikan serta diteladani pada setiap makna filosofisnya.

Dalam sebuah penelitian dikatakan bahwa Pendidikan karakter dapat membawa seseorang pada pengenalan nilai secara kognitif, penghayatan nilai secara afektif, yang akhirnya membawa pada pengamalan nilai secara nyata dalam kehidupan (Kurniawan, 2021). Sementara itu nilai kearifan lokal dapat berperan secara kritis untuk mengubah dan membentuk budaya global menjadi bermakna dan sesuai dengan kehidupan sosial budaya masyarakat (Miranti et al., 2021). Makna yang terdapat di dalam motif batik mampu menjadi media pembelajaran dan sarana pendidikan bagi masyarakat secara umum. Proses membatik yang relatif panjang memberikan gambara kepada manusia tentang pentingnya memiliki kesabaran untuk membuat hasil karya yang maksimal (Wansaka et al., 2018).

Berdasarkan latar belakang tersebut, pengkajian ini dilakukan untuk mengetahui nilai-nilai karakter yang terdapat dalam motif batik karya Sapuan yang berjudul Batik Dewa Ruci, diharapkan dengan pengkajian ini akan dapat mengupas nilai-nilai karakter baik dalam karya tersebut, dapat menginspirasi para pelaku budaya dan pendidik untuk terus berkarya, dan sekaligus untuk meneladankan karakter baik sebagai salah satu upaya untuk mengajarkan karakter kebaikan pada generasi muda.

\section{METODE PENELITIAN}

Kajian makna terhadap karya batik Sapuan ini, dilakukan dengan menggunakan metode kualitatif melalui wawancara langsung terhadap pembuat karya batik, didukung 
data pustaka dan dengan menggunakan pendekatan Hermeneutika. Dalam sebuah penelitian kualitatif terjadi sebuah penelitian studi kasus yang digunakan oleh peneliti dalam menganalisis topik tersebut (Creswell, 2012) sementara itu hermeneutika adalah kegiatan menafsirkan atau menginterpretasi, mengubah keadaan tidak tahu untuk menjadi tahu (Sumaryono dalam Ratnawati, 2010). Hermeneutika menafsirkan ekspresi penuh makna yang dengan sengaja digambarkan oleh seorang manusia, dengan kata lain interpretasi dilakukan pada hasil interpretasi seorang pribadi atau sekelompok manusia dalam situasi mereka sendiri ( Sutopo dalam Ratnawati, 2010). Pendekatan Hermeneutika penulis anggap paling cocok untuk mengkaji karya "Batik Dewa Ruci" dalam memaknai setiap ekspresi yang tergambar dalam karya Sapuan. Untuk kemudian mengkajinya dari sudut pandang teori pendidikan karakter oleh Thomas Lickona. Adapun langkah pengkajian dapat dilihat pada diagram berikut ini,

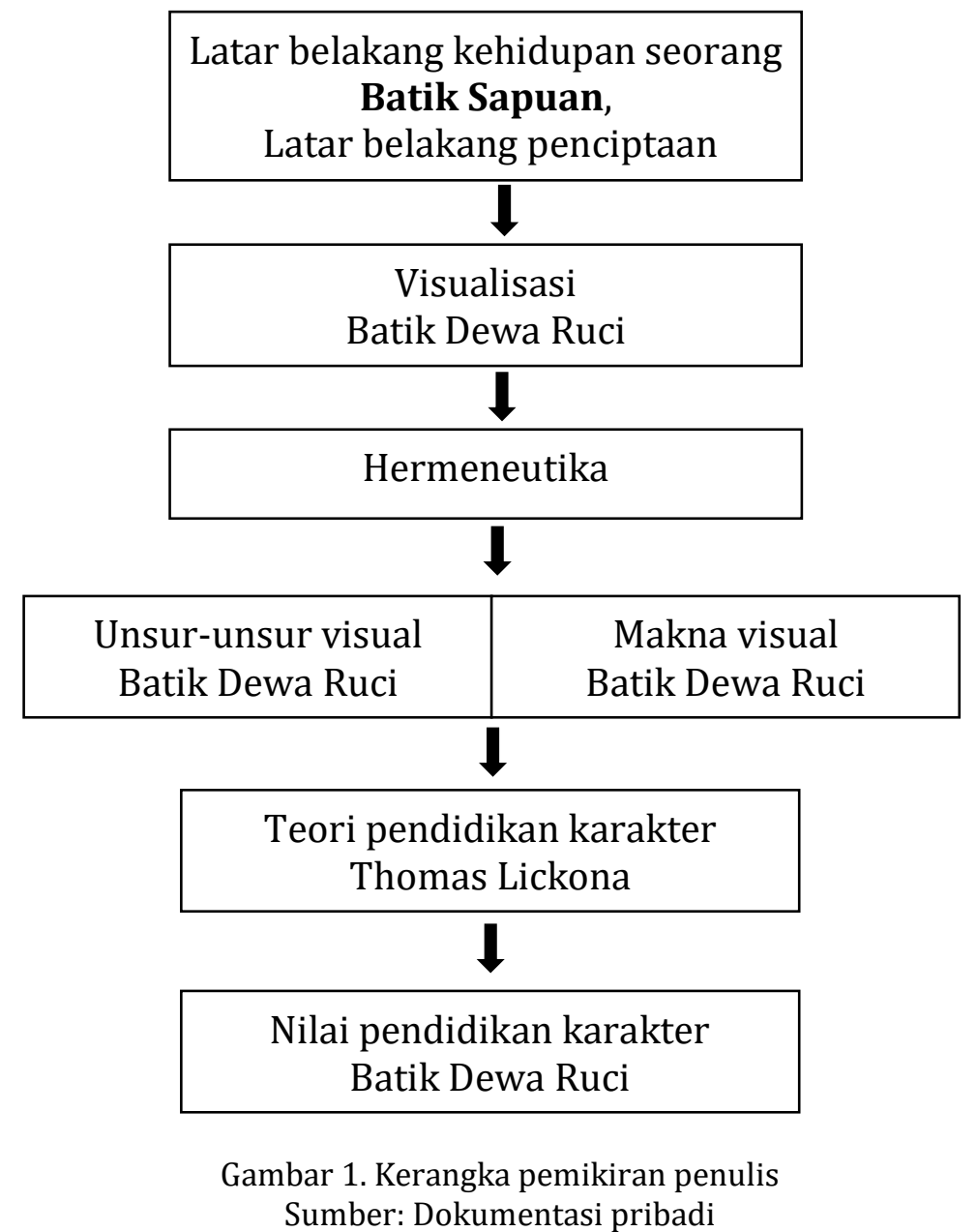

\section{HASIL DAN PEMBAHASAN}

\section{Batik Dewa Ruci Karya Sapuan}

Sapuan adalah seorag guru pengajar IPA di Sekolah Menengah Pertama (SMP) 2 Paningaran Kota Pekalongan. Latar belakang sebagai seorang guru mata pelajaran IPA menjadikan Sapuan memiliki pengetahuan dan pengalaman tersendiri dalam hal pewarnaan batik yang baik. Sebagai seorang pengajar sekaligus sebagai seorang seniman batik, Seorang Sapuan memiliki pandangan yang berbeda terhadap batik. Pandangan terhadap karya batik yang menurutnya batik bukanlah sekedar karya seni rupa, namun juga sebuah perjalanan kehidupan, sebuah proses ibadah, sebuah proses mendidik dan 
memberikan keteladanan. Pandangan ini diungkapkannya dalam berbagai kesempatan saat dia ditanya mengenai hakekat membatik. Termasuk pandangan ini disampaikan dalam percakapan dengan penulis melalui chat whatsapp. Demikian pandangan Sapuan dalam kutipan:

"Membatik adalah perjalanan religi, thoriqoh, persepsi saya bahwa ketika pelaku batik atau pembatik/pencanting menorehkan lilin pada kain sesungguhnya ia seperti sedang berkhalwat atau meditasi. Niati saja bahwa apa yg sedang ia lakukan (membatik/nyerat) karena Tuhan" (Sapuan, dalam percakapan bersama penulis).

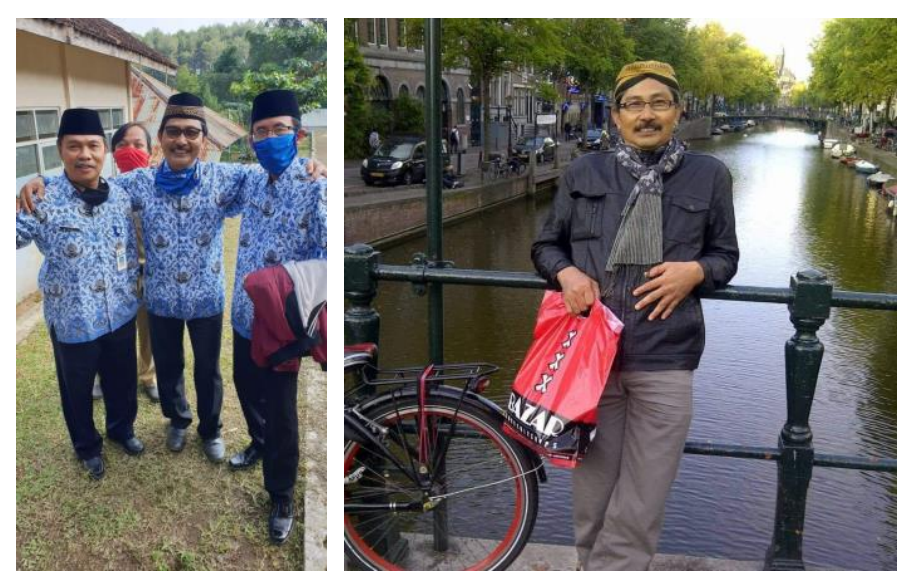

Gambar 2. Sapuan

Sumber gambar: Dok. Pribadi

Sapuan adalah seorang seniman batik yang senang untuk menceritakan hasil jelajah pikiran dan jiwanya dalam karya batik. Karya batik yang dihasilkannya selalu berekspresi dan sarat akan makna filosofis, seperti lukisan yang bertutur dan memiliki nilai seni yang tinggi. Karya batik sapuan dikerjakan dengan teknik batik tulis halus yang memegang teguh pakem pembuatan batik tradisional di masa lalu. Saat ini, disaat pembatik mulai meninggalkan teknik pembuatan batik halus, justru sapuan menerapkan teknik pembuatan batik halus pada setiap karyanya dengan menggunakan pewarnaan yang sangat baik, dan pemaknaan "story telling" dalam setiap karyanya. Sapuan sendiri adalah seorang yang religius, hampir pada setiap karyanya bermuatan nilai-nilai islami, yang mengandung ajaran hakekat keislaman. Batik menjadi jalan dakwah bagi seorang sapuan, sarana untuk mendidik dan berbagi pembelajaran kehidupan pada sesama. Bagi sapuan proses membatik ibarat perjalanan hidup anak manusia. Lebih lanjut sapuan mengatakan bahwa "Tidak ada seorangpun yang memiliki niatan jelek dalam kehidupannya atau ingin celaka, tetapi kehidupan manusia tidak terlepas dari kesalahan dan dosa, tidak apa-apa sebab ada pengampunan dari Allah SWT". Demikian sapuan memaknai sebuah proses membatik dengan segala kerumitannya. Karya karya Sapuan sudah banyak, sebagian telah menjadi koleksi negara dikarekan ke elokannya, bahkan menurut sebuah sumber media batik karya Sapuan disebut berharga dan laku dalam kisaran ratusan juta. Tidak salah bila kemudian seorang Sapuan kemudian disebut sebut sebagai maestro batik Indonesia.

Batik Dewa Ruci merupakan salah satu karya terbaik seorang Sapuan. Batik Dewa Ruci merupakan batik yang visualisasinya mengisahkan tentang cerita pewayangan bagian dari epos Mahabaratha. Kisah Dewa Ruci menceritakan tentang ketaatan seorang murid terhadap gurunya. Menggambarkan tentang sikap kemandirian, dan suatu perjuangan keras untuk menemukan jati diri manusia. Dikisahkan seorang pendawa yang kedua, bernama Werkudoro atau lebih dikenal dengan sebutan Bima. Bima memiliki 
karakter yang tidak cerdik, tidak pintar, polos tetapi memiliki kekuatan tersembunyi yang luar biasa. Pada suatu hari bima diperintahkan oleh gurunya "Resi Durno" untuk mencari air suci "prawitosari". Meski terlihat tidak masuk akal perintah gurunya, tetapi dengan takzim Bima tetap berangkat melaksanakan perintah tersebut dikarenakan Bima sangat hormat dan taat kepada perintah gurunya.

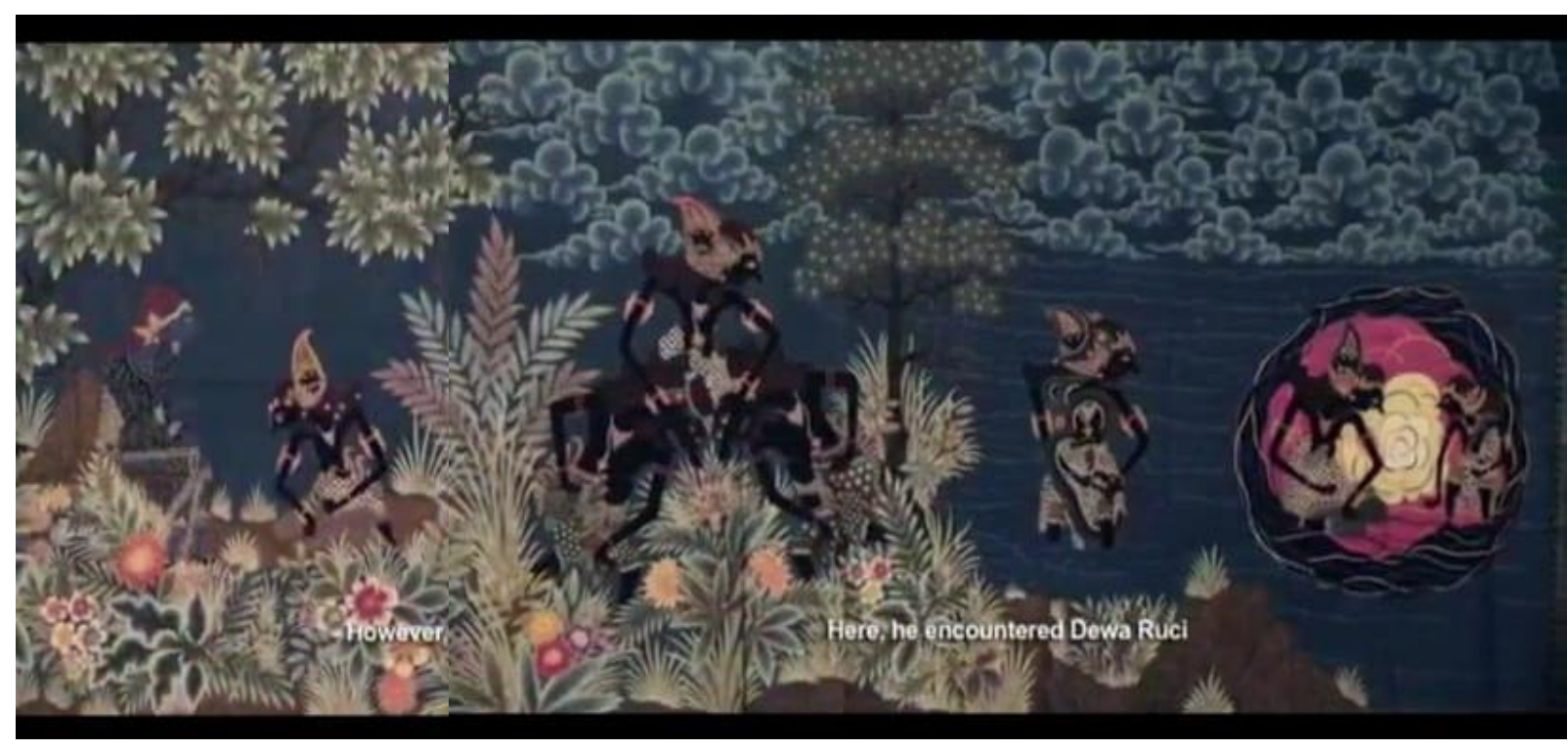

Gambar 3. "Batik Dewa Ruci"

Saat ini disimpan di museum tekstil Indonesia, Sumber gambar : dicuplik dari video Sapuan bersama Indosat (www.neighbourlist.com)

Bima tidak menyadari bahwa sebetulnya dirinya sedang dibohongi oleh sang guru, atau lebih tepatnya sedang diuji oleh sang guru. Tanpa rasa memiliki perasaan curiga Bima berangkat ke gunung, memasuki hutan "tribasoro" dan "reksomuka", di hutan tersebut Bima bertemu dengan raksasa "rukmuka" dan rukmala, dalam pertempuran tersebut Bima dapat mengalahkan raksasa dan kemudian pulang kembali kepada gurunya, dikarenakan Bima tidak menemukan air yang dimaksud. Melihat Bima kembali, sang guru heran semakin kagum dengan kekuatan Bima dalam mengalahkan raksasa. Sang guru kembali memerintahkan Bima untuk mencari air suci di lautan. Tanpa banyak bertanya berangkatlah Bima menuju lautan dengan berjalan kaki, di lautan Bima bertemu dengan naga Amburnawa, bertempurlah Bima dengan naga tersebut. Singkat kata naga Amburnawa pun kalah. Dalam perjalanan itu Bima bertemu dengan sosok wujud yang sangat kecil, bertubuh kerdil, namun memiliki wajah dan bentuk yang mirip seperti dirinya. Seperti sepasang manusia kembar, sosok itulah yang kemudian disebut sebagai "Dewa Ruci". Dalam tubuh "Dewa Ruci", melalui perjalanan gaib Bima melihat banyak peristiwa yakni : pancamaya, caturwarna, hastawarna, dan pramana (Setiawan, 2017). Dalam perjalanan panjang bersama "Dewa Ruci" akhirnya bima dapat menemukan jati dirinya, menjadi sosok insan kamil yang sempurna lahir dan bathin, dan sesungguhnya "Dewa Ruci" inilah jati diri seorang Bima atau Werkudoro.

\section{Unsur Visual Dan Makna Visual Batik Dewa Ruci}

Motif di dalam batik adalah kerangka gambar yang mewujudkan batik secara keseluruhan. Motif batik disebut juga sebagai corak batik atau pola batik. Menurut Sewan Susanto (1980:142) unsur pembentuk motif batik dapat dibagi menjadi dua bagian utama yakni, 1) Ornamen batik yang terdiri dari atas ornamen pokok dan ornamen pengisi. 2) 
Isen motif batik yang berupa titik, garis, atau gabungan titik dan garis. Ornamen pokok merupakan suatu ragam hias yang menentukan motif pada sebuah batik, biasanya ornamen pokok memiliki makna tertentu yang merepresentasikan makna dari motif tersebut. Sedangkan isen-isen berfungsi sebagai pengisi bidang diantara motif-motif tersebut.

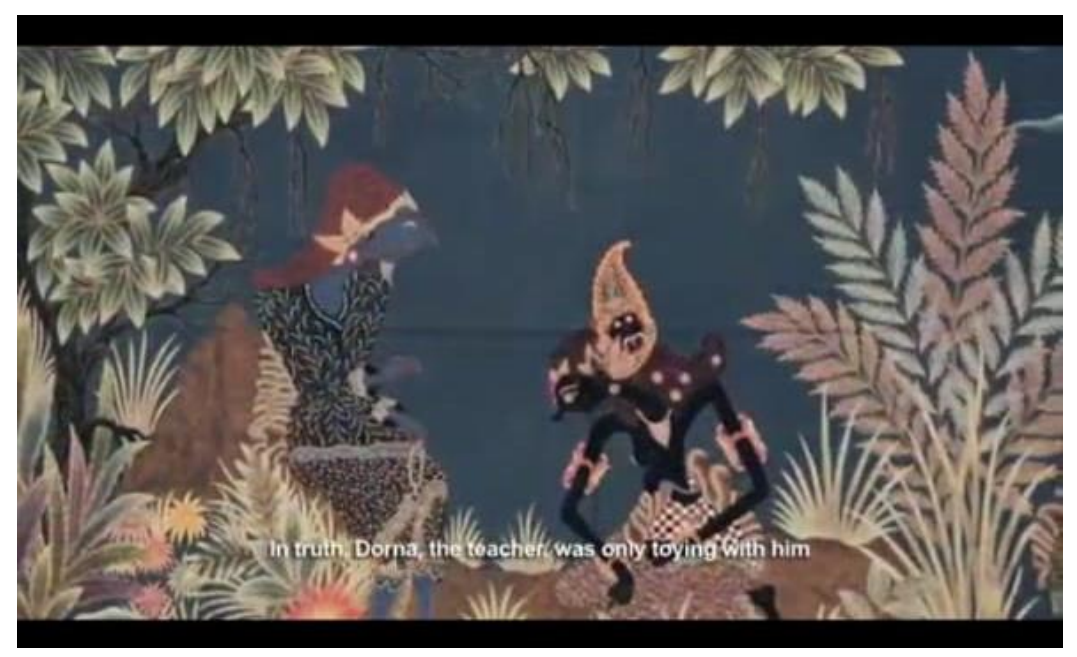

Gambar 4. Bima sedang menghadap sang guru "Resi Durno"

Sumber gambar : dicuplik dari video Sapuan bersama Indosat (www.neighbourlist.com)

Batik Dewa Ruci yang memiliki ornamen atau motif pokok pewayangan. Motif pokok pewayangan ini menggambarkan tentang perjalanan seorang Bima. Bima digambarkan sebagai sosok pewayangan berwarna hitam. Hitam merepresentasikan Bima sebagai sosok yang tidak pandai, tidak cerdik namun memiliki kekuatan yang luar biasa. Dengan warna latar batik berwarna biru malam, dan latar peristiwa atau cerita di hutan atau taman surga dengan pepohonan dan bunga-bunga yang indah. Latar warna biru menggambarkan ke-sakral-an peristiwa ini.

Dalam salah satu bagian batik digambarkan Bima sedang menghadap gurunya, untuk menerima sebuah perintah perjalanan mencari air suci, seperti pada kisah pewayangan Dewa Ruci. Dalam adegan tersebut digambarkan gesture atau bahasa tubuh Bima yang tampak tawadu' terhadap gurunya. Digambarkan Bima setengah membungkuk dengan kepala menghadap ke bawah. Sifat tawadu' adalah sifat rendah hati. Secara terminologis, tawadu merupakan akhlak mulia seorang manusia yang berisi kebaikan. Tawadu' merupakan pemaknaan dari sifat patuh, taat dan tunduk pada otoritas kebenaran, dan sikap sedia menerima kebenaran dari siapapun yang mengatakan, baik dalam keadaan ridha maupun marah. Sifat tawadu' merupakan ciri dari manusia yang luhur. Manusia yang luhur memiliki sifat tawadu, mencari guru yang baik, tidak bersifat keduniawian (zuhud), memiliki kontrol diri (mujahadah), menyendiri (uzlah), berserah diri kepada Tuhan (qanaah), merasa cukup dengan nikmat (tawakal), dan makrifat (Munandar \& Afifah, 2020).

Dalam adegan yang lain, pada Batik Dewa Ruci menvisualisasikan Bima sedang berada di hutan menghadapi dua raksasa, dan berada di lautan bertemu dengan Dewa Ruci. Pada penggalan visual inilah yang menjadi inti cerita dari perjalanan Bima dalam mencari jati dirinya. Hutan, gunung dan lautan merepresentasikan tantangan dan cobaan hidup manusia. Raksasa adalah representasi dari kemuliaan, kekayaan, kebesaran, kehebatan, sekaligus nafsu dan angkara manusia. Sifat yang disimbolkan oleh raksasa ini merupakan sifat-sifat manusiawi yang seringkali membuat manusia merasa sombong dan 
pongah. Mengalahkan raksasa berarti mengalahkan nafsu dan angkara yang ada dalam diri manusia itu sendiri.

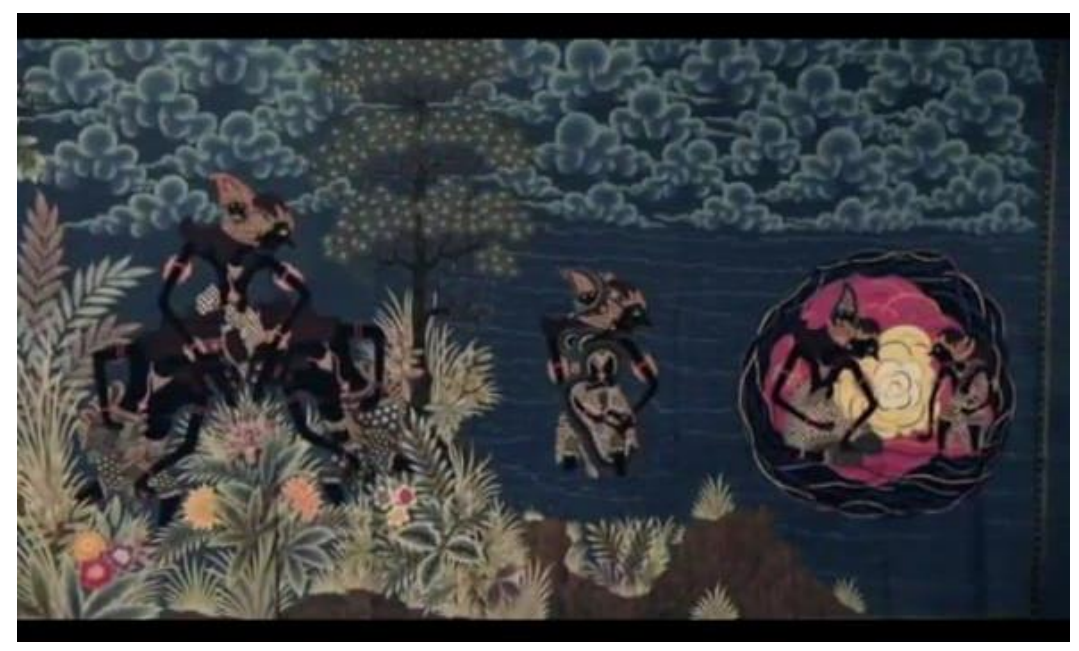

Gambar 5. Bima sedang menghadapi raksasa di hutan, serta bertemu dengan Dewa Ruci di lautan.

Sumber gambar : dicuplik dari video Sapuan bersama Indosat (www.neighbourlist.com)

Pertemuan dengan Dewa Ruci di lautan digambarkan berada dalam lingkaran asap berwarna keunguan. Dewa Ruci digambarkan sebagai sosok yang menyerupai Bima, perbedaannya terletak pada ukuran tubuh keduanya, Dewa Ruci bertubuh kerdil. Sosok dewa Ruci yang bertubuh kerdil merepresentasikan hakekat manusia yang sesungguhnya kecil di mata sang pencipta. Dewa Ruci sendiri dalam kisah pewayangan merupakan sosok jati diri dari Bima. Pemilihan warna ungu di dalam karya selain untuk menggambarkan kesakralan dalam cerita juga menguatkan makna akan kesedihan dalam diri Bima, kekosongan, dan pencarian jati diri yang dilakukan oleh Bima. Kekosongan jiwa yang mungkin dialami Bima dalam perjalanan hidup sebelum bertemu dengan Dewa Ruci.

\section{Pendidikan Karakter Dari Prespektif Thomas Lickona}

Dr Thomas Lickona, adalah seorang psikolog perkembangan dan profesor pendidikan di Universitas Negara Bagian New York di Cortland. Dr. Thomas Lickona sering menjadi konsultan di sekolah-sekolah mengenai pendidikan karakter dan menjadi pembicara di berbagai seminar untuk para pendidik, orang tua, pendidik agama, dan kelompok yang peduli akan perkembangan moral kaum muda. Ia mengajar nilai moral baik di sekolah maupun di rumah mulai dari Amerika Serikat, Kanada, jepang, Singapura, Swis, Irlandia, dan Amerika Latin. Thomas Lickona memperoleh gelar Ph.D dalam bidang psikologi dari State University of New York, Albany dengan risetnya mengenai perkembangan penalaran moral anak-anak. Ia menerima penghargaan alumni kehormatan, Distinguished Alumni Award dari State university of new York di Albany (Hasan, 2018).

Menurut Thomas Lickona, karakter sangat berkaitan dengan konsep moral (moral knowing), sikap moral (moral felling), dan perilaku moral (moral behavior). Berdasarkan ketiga komponen ini dapat dinyatakan bahwa karakter yang baik didukung oleh pengetahuan tentang kebaikan, keinginan untuk berbuat baik, dan melakukan perbuatan kebaikan. Berkaitan dengan hal ini Thomas Lickona, juga mengemukakan: "Character education is the deliberate effort to help people understand, care about, and act upon core ethical values" (Pendidikan karakter adalah usaha sengaja (sadar) untuk membantu 
manusia memahami, peduli tentang, dan melaksanakan nilai-nilai etika inti). Bahkan dalam buku Character Matters dia menyebutkan: Character education is the deliberate effort to cultivate virtue - that is objectively good human qualities-that are good for the individual person and good for the whole society (Pendidikan karakter adalah usaha sengaja (sadar) untuk mewujudkan kebajikan, yaitu kualitas kemanusiaan yang baik secara objektif, bukan hanya baik untuk individu perseorangan, tetapi juga baik untuk masyarakat secara keseluruhan) (Lickona, 2012).

Thomas Lickona (dalam Dalmeri, 2014). menyebutkan tujuh unsur-unsur karakter esensial dan utama yang harus ditanamkan kepada peserta didik yang meliputi:

1. Ketulusan hati atau kejujuran (honesty);

2. Belas kasih (compassion);

3. Kegagahberanian (courage);

4. Kasih sayang (kindness);

5. Kontrol diri (self-control);

6. Kerja sama (cooperation);

7. Kerja keras (deligence or hard work).

Tujuh karater inti (core characters) inilah, menurut Thomas Lickona, yang paling penting dan mendasar untuk dapat dikembangan pada peserta didik, selain unsur-unsur karakter lainnya. Apabila dianalisis dari prespektif kepentingan perbaikan kehidupan Bangsa Indonesia ketujuh karakter tersebut memang diperlukan menjadi bagian atau unsur yang amat esensial dalam menjada serta mengembangkan jati diri bangsa melalui pendidikan karakter. Di antaranya, unsur kejujuran, Bangsa Indonesia saat ini sangat membutuhkan kehadiran sosok manusia yang memiliki tingkat kejujuran yang tinggi. Sementara itu yang terjadi di lapangan adalah hilangnya nilai kejujuran dalam kehidupan Indonesia. Membiarkan ketidakjujuran menjadi salah satu tanda kehancuran bangsa. Unsur karakter yang ketujuh adalah kerja keras (diligence or hard work), sikap ini diperlukan untuk membangun Bangsa, menjadikan Indonesia menjadi negara maju yang cerdas dengan tetap memegang teguh prinsip Bangsa.

Penanaman karakter dalam diri manusia membutuhkan keteladanan dari seorang guru, seorang guru harus dapat menghindari sikap pilih kasih, kasar, harus dapat memperlakukan seorang siswa dengan rasa hormat dan rasa kasih sayang, dan melakukan pembimbingan terhadap siswa, satu per satu dengan cara memahami bakat khusus yang dimiliki masing- masing anak (Kuswandi, 2020). Di dalam kisah pewayangan Dewa Ruci ini keteladanan seorang guru dicontohkan dengan jelas dari perilaku seorang Resi Durna (seorang guru) terhadap Bima (seorang murid).

\section{Nilai Pendidikan Karakter Motif Batik Dewa Ruci}

Nilai karakter yang terdapat dalam motif Batik Dewa Ruci dapat diurai dari visualisasi motif batik tersebut. Pengalaman spiritual perjalanan tokoh Bima yang divisualisasikan dalam motif Batik, tergambar dengan sangat jelas. Penggambaran karakter Bima yang bertubuh besar dan hitam, serta tokoh Dewa Ruci yang bertubuh mungil dan hitam menjadi gambaran tepat bagi sosok manusia masa kini. Sosok manusia yang bertubuh besar dan gelap seolah menggambarkan sifat yang kelam dan jahat, akan tetapi dengan memahami jalan cerita yang sesungguhnya manusia diajarkan untuk tidak berburuk sangka sebelum mengerti keadaan yang sesungguhnya. Hal ini sesuai dengan konsep karakter baik yang digagas oleh Thomas Lickona yakni kontrol diri (self-control). Dimana manusia dengan karakter yang baik haruslah dapat mengontrol dirinya dalam segala keadaan, untuk tidak mudah memberikan penilaian terhadap sesama dan lingkungan sebelum memahami permasalahan yang sesungguhnya, serta untuk dapat 
mengotrol diri pada saat menghadapi ujian, dalam hal ini tidak menjadi seorang pemarah seperti yang dicontohkan dalam karakter Bima.

Sosok Bima dan kisah spritualnya dapat menjadi teladan yang baik bagi manusia masa kini. Bima dan pengalaman dalam perjalannya bertemu Dewa Ruci telah memberikan teladan yang baik tentang karakter baik dalam kehidupan. 7 karakter kebaikan versi Thomas lickona nampak jelas dalam sosok Bima. Bima tergambar sebagai sosok yang memiliki kejujuran tinggi, memiliki sifat kegagah beranian, dan sosok yang tawadhu. Tawadhu merupakan sebuah cerminan nilai karakter religius yang dapat diartikan sebagai sifat keberimanan terhadap Tuhan yang Maha Esa yang terwujud dalam perilaku melakukan ajaran agama dan kepercayaan sesuai yang dianut, menghargai adanya perbedaan agama, menjunjung tinggi sikap toleransi terhadap sesama, mengutamakan kerukunan hidup dan kedamaian dengan pemeluk agama lain. Pengimplementasian nilai karakter religius mewakili karakter kebaikan dalam kehidupan, yang ditunjukkan dalam sikap mencintai kedamaian, toleransi, menghargai perbedaan, teguh pendirian, memiliki rasa percaya diri, berkerja sama antar pemeluk agama dan kepercayaan, anti perundungan dan kekerasan, memiliki rasa persahabatan, tulus, tidak suka memaksakan kehendak pribadi, cinta lingkungan, memberikan perlindungan pada yang lemah (Idris, 2019).

\section{SIMPULAN}

Penciptaan Batik Dewa Ruci sangat dipengaruhi oleh latar belakang pencipta. Sapuan sebagai seorang pendidik, memiliki naluri yang kuat untuk terus mendidik, menyebarkan ilmu dan pembelajaran. Jiwa mendidik ini yang kemudian Sapuan tuangkan dalam karya yang diciptakan. Didukung dengan sifat religi yang dimiliki oleh seorang Sapuan, karya ini menjadi sempurna dalam goresan canting Sapuan. Tak hanya indah secara visual, secara nilai filosofis pun karya ini memiliki makna yang sangat dalam dan berharga.

Secara filosofis Batik Dewa Ruci menggambarkan perjalanan hidup manusia. sebelum bertemu dengan sang pencipta. Di dalam perjalanan hidup manusia pasti bertemu dengan ujian dan cobaan. Sosok Bima memberikan tauladan yang baik, mengajarkan bagaimana manusia yang luhur seharusnya bersikap. Taat kepada guru dan mencari guru yang baik adalah salah satu cara yang harus ditempuh oleh seorang manusia untuk dapat menemukan jati diri dan hakekat kehidupan yang sesungguhnya. Perjalanan Bima sebelum bertemu dengan Dewa ruci mengajarkan manusia untuk memberikan perlawanan kepada hawa nafsu dan angkara yang menjadi sifat dasar dalam pribadi manusia. Dewa Ruci adalah ilmu sejati yang menjadi simbol jati diri manusia, bahwa sesengguhnya manusia adalah kerdil, kecil, dimata Sang Pencipta.

Cerita inspirasi wayang lakon Dewa Ruci sebagai karya sastra Jawa secara tersirat dan juga secara tersurat sangat sarat mengandung sisi keteladanan yang mendidik. Kisah inspirasi Dewa Ruci dalam pewayangan merupakan warisan budaya yang sangat besar manfaatnya terutama dari sisi keteladanan baik dari para tokohnya (Isnaniah, 2010). Ditinjau dari prespetif Thomas Lickona, motif batik Dewa Ruci memuat nilai-nilai karakter kebaikan. Motif batik Dewa Ruci mampu mengidentifikasikan kualitas moral dengan ciriciri karakter baik, yang mencakup pengetahuan moral, perasaan moral dan juga tindakan moral dalam kehidupan, yang kesemua komponen karakter tersebut tervisualisakan dengan baik dan jelas dalam karya batik Dewa Ruci.

\section{UCAPAN TERIMAKASIH}

Ucapan terimakasih yang sebesar-besarnya disampaikan kepada Bapak Sapuan, seorang guru yang mengisnpirasi, seorang perupa yang mengilhami, terima kasih telah 
mengijinkan untuk sekedar memberikan apresiasi terhadap karya Batik Dewa Ruci, terima kasih telah membagikan segala informasi yang dari informasi tersebut, penulis dapat belajar dan kemudian menuliskan kembali dalam artikel, tentang sebuah maha karya batik yang tidak hanya indah tetapi juga memberikan keteladanan dalam kehidupan.

\section{DAFTAR PUSTAKA}

Ariandy, M. (2019). Kebijakan Kurikulum dan Dinamika Penguatan Pendidikan Karakter di Indonesia. Sukma: Jurnal Pendidikan, 3(2), 137-168.

Arifiyanti, K., Untari, M. F. A., \& Wardana, M. Y. S. (2018). Analisis Motif Batik Rifa'iyah Sebagai Penanaman Nilai-Nilai Karakter Dalam Pembelajaran Membatik Di Sdn Wonobodro 01 Batang. SENDIKA [Seminar Nasional Pendidikan], 856-864.

Dalmeri. (2014). Pendidikan Untuk Pengembangan Karakter (Telaah terhadap Gagasan Thomas Lickona dalam Educating for Character). Al-Ulum, 269-288.

Hasan, S. (2018). Analisis Komparatif Konsep Pendidikan Karakter Perspektif Thomas Lickona dan al-Zarnuji Serta Implikasinya Terhadap Pendidikan Agama Islam. https://doi.org/10.31219/osf.io/5eaks

Idris, M. (2019). Pendidikan Karakter : Perpektif Islam Dan Thomas Lickona. Ta'dibi : Jurnal Manajemen Pendidikan Islam, VII(September 2018).

Isnaniah, S. (2010). Dewa Ruci : Sebuah Alternatif Sistem Pendidikan.

Kurniawan, G. P. (2021). Analisis Makna Filosofis Motif Batik Ponorogo Sebagai Upaya Penanaman Pendidikan Karakter. Attractive : Innovative Education Journal, 3(2).

Kuswandi, I. (2020). TAHAPAN PENGEMBANGAN MORAL: PERSPEKTIF BARAT DAN ISLAM (Telaah Terhadap Gagasan Thomas Lickona, Lawrence Kohlberg dan Al-Qur'an). Ar-Risalah: Media Keislaman, Pendidikan Dan Hukum Islam, XVIII.

Lickona, T (2012) Character Matters: Persoalan Karakter, terj. Juma Wadu Wamaungu \& Jean Antunes Rudolf Zien dan Editor Uyu Wahyuddin dan Suryani, Jakarta: Bumi Aksara.

Lickona, T (2012) Educating for Character: Mendidik untk Membentuk Karakter, terj. Juma Wadu Wamaungu dan Editor Uyu Wahyuddin dan Suryani, Jakarta: Bumi Aksara.

Mahliana, L., \& Mustikarini, I. D. (2013). Pendidikan karakter anak melalui seni batik. Citizenship Jurnal Pancasila, 119-134. e-journal.unipma.ac.id

Miranti, A., Winarni, R., \& Surya, A. (2021). Representasi Pendidikan Karakter Berbassis Kearifan Lokal dalam Motif Batik Wahyu Ngawiyatan sebagai Muatan Pendidikan Senirupa di Sekolah Dasar.JURNAL BASICEDU, 5(2), 546-560. https://doi.org/https://doi.org/10.31004/basicedu.v5i2.763

Munandar, S. A., \& Afifah, A. (2020). Ajaran Tasawuf Dalam Serat Wedhatama Karya K.G.P.A.A Mangkunegara IV. 10(Februari), 51-75.

Munawaroh, A. (2019). Keteladanan Sebagai Metode Pendidikan Karakter. Jurnal Penelitian Pendidikan Islam, 7(2).

Ratnawati, I. (2010). Kajian Makna Filosofi Motif Batik Gajah Oling Banyuwangi. Universitas Pendidikan Indonesia.

Setiawan, E. (2017). Makna Filosofi Wayang Purwa Dalam Lakon Dewa Ruci.

Susanto, S.K Sewan (1980) 'SENI BATIK INDONESIA', Balai Besar kerajinan dan Batik, Andi Offset, Yogyakarta.

Wansaka, A., Hidayah, H. N., \& Bakhittah, H. A. (2018). Kampung Batik Manding Siberkreasi Sebagai Model Pelestarian. JPSI, 2, 122-140.

https://www.neighbourlist.com/2015/01/indosat-presents-batikology-art-batik-dewa-ruci/tanggal 12 $\underline{\text { April } 2021}$ 